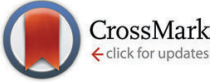

Cite this: Phys. Chem. Chem. Phys., 2016, 18, 8890

Received 16th October 2015, Accepted 25th February 2016

DOI: $10.1039 / c 5 c p 06301 a$

www.rsc.org/pccp

\section{The role of conserved Cys residues in Brassica rapa auxin amidohydrolase: Cys139 is crucial for the enzyme activity and Cys320 regulates enzyme stability $\dagger$}

\author{
Ana Smolko, ${ }^{a}$ Filip Šupljika, ${ }^{b}$ Jelena Martinčić, ${ }^{a}$ Nina Jajčanin-Jozić, ${ }^{b}$ \\ Marina Grabar-Branilović, ${ }^{c}$ Sanja Tomić, ${ }^{c}$ Jutta Ludwig-Müller, ${ }^{d}$ Ivo Piantanidał‡b \\ and Branka Salopek-Sondi*a
}

\begin{abstract}
Brassica rapa auxin amidohydrolase (BrILL2) participates in the homeostasis of the plant hormones auxins by hydrolyzing the amino acid conjugates of auxins, thereby releasing the free active form of hormones. Herein, the potential role of the two conserved Cys residues of BrILL2 (at sequence positions 139 and 320) has been investigated by using interdisciplinary approaches and methods of molecular biology, biochemistry, biophysics and molecular modelling. The obtained results show that both Cys residues participate in the regulation of enzyme activity. Cys320 located in the satellite domain of the enzyme is mainly responsible for protein stability and regulation of enzyme activity through polymer formation, as has been revealed by enzyme kinetics and differential scanning calorimetry analysis of the BrILL2 wild type and mutants C320S and C139S. Cys139 positioned in the active site of the catalytic domain is involved in the coordination of one $\mathrm{Mn}^{2+}$ ion of the bimetal center and is crucial for the enzymatic activity. Although the point mutation Cys139 to Ser causes the loss of enzyme activity, it does not affect the metal binding to the BrILL2 enzyme, as has been shown by isothermal titration calorimetry, circular dichroism spectropolarimetry and differential scanning calorimetry data. MD simulations (200 ns) revealed a different active site architecture of the BrILL2C139S mutant in comparison to the wild type enzyme. Additional possible reasons for the inactivity of the BrILL2C139S mutant have been discussed based on MD simulations and MM-PBSA free energy calculations of BrILL2 enzyme complexes (wt and C139S mutant) with IPA-Ala as a substrate.
\end{abstract}

\section{Introduction}

Auxin amidohydrolases belong to the metallopeptidase family M20, subfamily M20D (MEROPS: the Peptidase Database, http://merops.sanger.ac.uk/), ${ }^{1}$ and are related to the amidohydrolase superfamily. The enzymes of the amidohydrolase superfamily catalyze the hydrolysis of a wide range of substrates containing amide or ester functional groups at carbon and phosphorus centers. ${ }^{2}$ Reactions catalyzed by enzymes in this superfamily include deamination, dephosphorylation, decarboxylation,

\footnotetext{
${ }^{a}$ Division of Molecular Biology, Ruđer Bošković Institute, 10000 Zagreb, Croatia. E-mail: salopek@irb.hr; Fax: +385-1-4561-177; Tel: +385-1-4561-143

${ }^{b}$ Division of Organic Chemistry and Biochemistry, Ruđer Bošković Institute, 10000 Zagreb, Croatia. E-mail: ivo.piantanida@irb.hr

${ }^{c}$ Division of Physical Chemistry, Ruđer Bošković Institute, 10000 Zagreb, Croatia

${ }^{d}$ Institute of Botany, Technische Universität Dresden, 01062 Dresden, Germany

$\dagger$ Electronic supplementary information (ESI) available: CDS Fig. S1, ITC Fig. S2-S4 and MD simulations Fig. S5-S10 of BrILL2 wt and mutants, DSC Fig. S11-S13 and Tables S1-S7. See DOI: 10.1039/c5cp06301a

\# Corresponding author for biophysical part of research.
}

dechlorination, and isomerization, and are important in amino acid and nucleotide metabolisms as well as biodegradation of agricultural and industrial compounds. Many enzymes in the M20 peptidase family are $\mathrm{Zn}^{2+}$-dependent, but the auxin amidohydrolases prefer $\mathrm{Mn}^{2+}$ as a metal cofactor. They participate in the regulation of the activity of the plant hormones auxins. ${ }^{3,4}$ Auxins are well known as crucial plant hormones involved in many aspects of growth and development, such as cell division, cell elongation, root and shoot growth, flower and fruit development, and tropisms. High concentrations of free auxins, of which the most common is indole-3-acetic acid (IAA), are toxic for plants, so only about 5\% of the total concentration of auxin molecules in plants is in the free (active) form, while the rest is stored in inactive forms, mostly as amino acid and sugar conjugates. ${ }^{3}$ Different plant species have distinct profiles of auxin conjugates; monocots store preferably ester conjugates, whereas dicots synthesize mostly amide conjugates. ${ }^{5}$

Auxin amidohydrolases specifically hydrolyze the amide bond of amino acid conjugated auxins, releasing free active compounds. Such hydrolases (named ILR, IAR and ILL) were first 
cloned from Arabidopsis thaliana, ${ }^{6-8}$ and the purified recombinant proteins showed activity towards the conjugates of the most common auxin IAA, with a variety of amino acids. Homologous amidohydrolases from Triticum aestivum, Medicago truncatula, and Brassica rapa were found to be more active towards amino acid conjugates of long-chained auxins: indole-3-butyric acid (IBA-Ala) and indole-3-propionic acid (IPA-Ala) in comparison to IAA-Ala. ${ }^{9-11}$

Although these proteins have been known for quite some time, their structure-function relationship is still not clear. The first X-ray structure of a plant enzyme (ILL2 from Arabidopsis thaliana) has been reported as an apoenzyme, ${ }^{12,13}$ still missing details about the substrate binding site and the amino acid residues important for substrate specificity. Based on the modelling results, a potential substrate binding cleft has been proposed for the Arabidopsis enzyme (AtILL2), ${ }^{13}$ as well as for the Brassica rapa enzyme (BrILL2), ${ }^{11}$ in which several substrate binding modes for the preferred long-chained auxin conjugates were additionally predicted. Details of the active site of a similar enzyme, $(S)$-ureidoglycolate amidohydrolase, have recently been reported. ${ }^{14}$ Structurally, auxin amidohydrolases are characterized by two perpendicular domains with the larger catalytic domain bearing a binuclear metal center, and the smaller "satellite" domain, usually functioning as a polymerization site (Fig. 1).

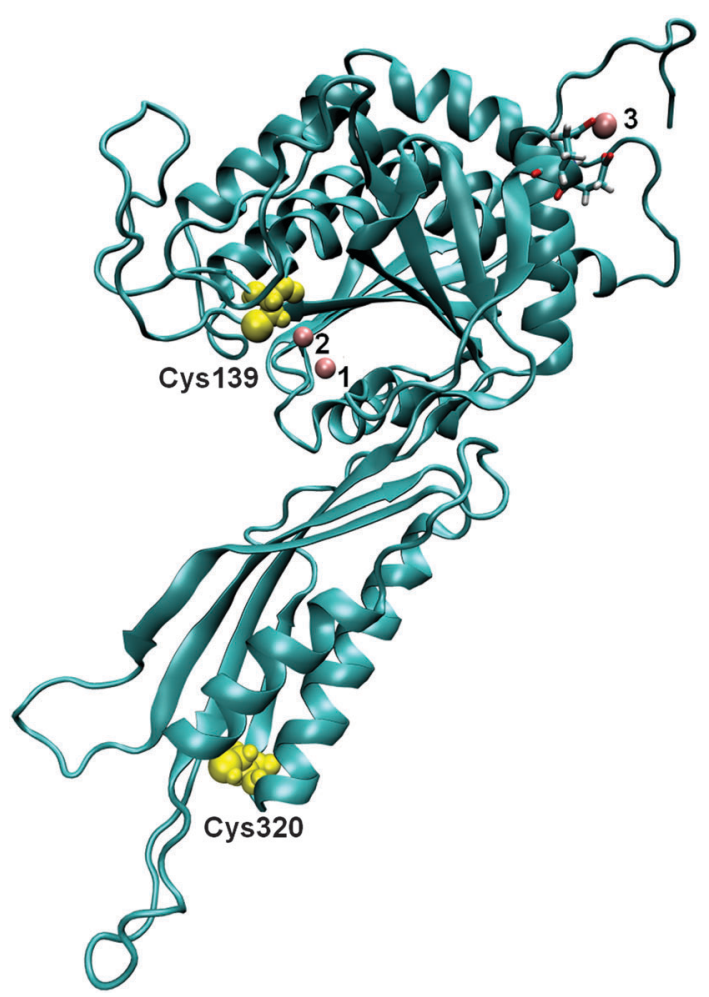

Fig. 1 The 3D structure of BrILL2 obtained by comparative modelling Three $\mathrm{Mn}^{2+}$ ions are presented as violet spheres (numbered 1, 2 and 3). Two of them ( 1 and 2 ) are placed in the active site within the protein according to their position in the structure of an amidohydrolase, SACOL0085, from methicillin-resistant Staphylococcus aureus (pdb: 4EWT). The position of the third one was determined by molecular modelling. The positions of two cysteine residues are shown as yellow spheres: Cys139 near the active site within the catalytic domain and Cys320 within the smaller satellite domain.
The larger domain contains the active site and consists of $\beta$-strands with $\alpha$-helical bundles on both sides. The smaller satellite domain adopts an $\alpha / \beta$-sandwich topology. In other M20 peptidases, the satellite domain serves as a dimerization interface. However, auxin amidohydrolases function as monomers and need a reducing agent, such as dithiothreitol (DTT) for their activity in the enzyme assay in vitro. ${ }^{11}$

Based on the sequence homology, auxin amidohydrolases contain two highly conserved cysteine residues. ${ }^{11}$ It has been proposed previously that one of the two conserved Cys residues in the B. rapa ILL2 enzyme, Cys139, is a part of the active site and coordinates the metal co-factor. ${ }^{11}$

Based on our previous finding that the activity of BrILL2 depends on a reducing agent, and since molecular modelling indicated the importance of Cys, we undertook this study to examine the potential role of the conserved Cys residues in this metalloenzyme. For that purpose, Cys mutants (C139S and C320S as well as the double mutant C139,320S) were generated and comparative biochemical characterization of the mutant and the wild type enzymes was performed, including the determination of enzyme kinetics with the substrate IPA-Ala. Furthermore, our research involved biophysical (HR-ICP-MS, ITC, CDS, and DSC) and theoretical (MD simulations) studies in order to examine metal binding to the enzyme, and the importance of Cys139 in the coordination of the metal cofactor. Finally, the role of Cys residues in the enzyme activity regulation will also be discussed.

\section{Results and discussion}

\subsection{Importance of the conserved Cys residues for enzyme activity and stability}

The auxin amidohydrolase BrILL2 contains two highly conserved cysteine residues (Cys139 and Cys320) (Fig. 1). Many proteins and enzymes in the cell contain cysteine residues which have a sulfhydryl group in their side chain and with the labile proton which makes it a chemical hot spot for a wide variety of biochemical interactions. Such a thiol group provides sites for the formation of coordinate bonds with metal ions, sites for electrophilic reactions, and an easily reversible site for oxidation/reduction chemistry. The importance of Cys residues for the BrILL2 enzyme activity was firstly noticed by pre-treatments of the BrILL2 wild type (wt) enzyme with iodoacetamide (I-acetamide). The enzyme irreversibly lost activity due to alkylation by I-acetamide. Based on the proposed model of the active site, Cys139 is suggested as a residue of the binding pocket and potentially participates in metal binding. To prove this assumption, we generated mutants in which Cys residues were replaced by Ser amino acids, and investigated the role of Cys residues in the regulation of enzyme activity.

The results of CD spectropolarimetry of the mutant enzymes (ESI, $\dagger$ Fig. S1) confirmed that none of the mutations changed the secondary structure of the protein, thus excluding structure perturbations as possible reasons for changes in the enzyme activity. Based on our specific enzyme activity assay, the BrILL2C139S 
Table 1 Kinetic parameters of the BrILL2 enzyme, wt and mutants C139S and C320S, and double mutant C139,320S. Measurements were performed using the substrate IPA-Ala in the range of $0.2-2 \mathrm{mM}$. The protein concentration was $2.008 \times 10^{-7} \mathrm{M}$. nd - not determined. The values are average $\pm \mathrm{SE}$

\begin{tabular}{|c|c|c|c|c|c|}
\hline Protein & $\begin{array}{l}\text { Specific activity } \\
\left(\mathrm{nmol} \mathrm{mg}^{-1} \mathrm{~min}^{-1}\right)\end{array}$ & $V_{\max }\left(\mu \mathrm{M} \min ^{-1}\right)$ & $K_{\mathrm{m}}(\mathrm{mM})$ & $K_{\text {cat }}\left(\min ^{-1}\right)$ & $\begin{array}{l}K_{\text {cat }} / K_{\mathrm{m}} \\
\left(\mathrm{mM}^{-1} \min ^{-1}\right)\end{array}$ \\
\hline Wt & $2261 \pm 320$ & $0.0316 \pm 0.005$ & $0.61 \pm 0.3$ & $157 \pm 25$ & 258.4 \\
\hline C320S & $1143 \pm 18$ & $0.0195 \pm 0.002$ & $0.59 \pm 0.18$ & $97 \pm 11$ & 163.7 \\
\hline C139,320S & nd & nd & nd & nd & nd \\
\hline
\end{tabular}

mutant was inactive, while the BrILL2C320S mutant appeared to be approximately $38 \%$ less active in comparison to BrILL2wt (Table 1). Furthermore, enzyme kinetics experiments with the substrate IPA-Ala were performed with the active mutant C320S and wt enzymes. As can be seen the $K_{\mathrm{m}}$ value has not been changed for the C320S mutant, while the $K_{\text {cat }}$ was 1.6-fold lower for the C320S mutant in comparison to the wt. It seems that the Cys320 residue influenced the enzyme activity regardless of its distance from the active site. So what could be the role of a distant Cys residue in the regulation of BrILL2 activity? As we already mentioned, auxin amidohydrolases are active in the monomeric form. In the absence of a reducing agent, BrILL2 is prone to form dimers and even higher oligomers, which are not active in an in vitro enzyme assay. To investigate whether Cys residues have a role in the oligomer formation, we have applied gradient SDS-PAGE and Western blot analysis using anti-His-tag antibodies and compared the potential of the BrILL2wt and the mutants C139S, C320S and C139,320S for polymerization under reducing $v s$. non-reducing conditions (Fig. 2). As can be seen, the wild type BrILL2 forms dimers and higher oligomers under non-reducing conditions. Similarly, both C139S and C320S are capable of forming dimers to a lesser extent than BrILL2wt, whereas this capacity is completely absent in the double C139,320S mutant. To learn more about the enzyme stability under reducing and non-reducing conditions, differential scanning calorimetry (DSC) measurements were done (Table 2) in parallel with Western blot analysis (Fig. 2).

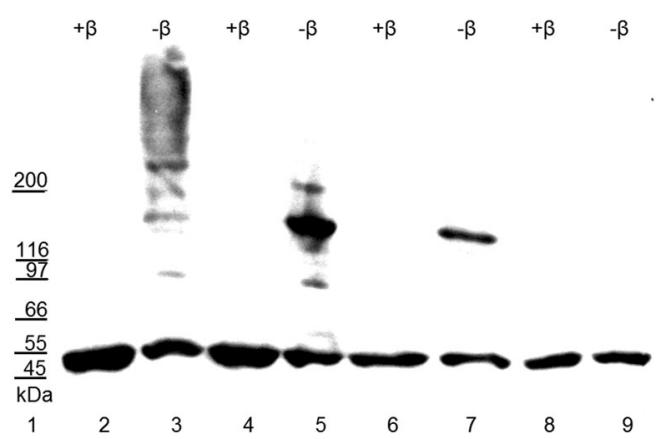

Fig. 2 Electro-blot of the purified recombinant BrILL2 enzymes (wt and mutants) resolved by SDS-PAGE in 4-20\% gradient gel under non-reducing conditions $(-\beta)$, and reducing conditions by adding $\beta$-mercaptoethanol $(+\beta)$. Proteins were blotted onto a PVDF membrane and visualized by chemiluminescence with the use of anti-His-tag antibodies. Lane: 1 , molecular weight markers; 2-3, wt BrILL2; 4-5, mutant C139S; 6-7, mutant C320S; 8-9, double mutant C139,320S. $4 \mu \mathrm{g}$ (lanes 6-9) or $5 \mu \mathrm{g}$ (lanes 2-5) of proteins was loaded onto gel lanes.
Table 2 Parameters of DSC measurements of BrILL2, wt and mutants under the non-reducing conditions (the absence of $\beta$-mercaptoethanol, $-\beta$ ), and reducing conditions (addition of $5 \mathrm{mM} \beta$-mercaptoethanol, $+\beta$ ) obtained during heating from 25 to $90{ }^{\circ} \mathrm{C}$ at a rate of $1{ }^{\circ} \mathrm{C} \mathrm{min}^{-1}$. nd - not determined

\begin{tabular}{llll}
\hline BrILL2 & $T_{\max }{ }^{\circ} \mathrm{C}$ & $\Delta_{\mathrm{r}} H / \mathrm{kJ} \mathrm{mol}^{-1}$ & $\Delta_{\mathrm{r}} S / \mathrm{J} \mathrm{K}{ }^{-1} \mathrm{~mol}^{-1}$ \\
\hline wt $-\beta$ & 56.4 & 60.6 & 183.7 \\
wt $+\beta$ & 54.4 & 89.6 & 273.5 \\
C139S $-\beta$ & 56.8 & 93.8 & 284.3 \\
C139S $+\beta$ & 55.2 & nd & nd \\
C320S $-\beta$ & 53.4 & 59.6 & 182.4 \\
C320S $+\beta$ & 52.2 & 16.8 & 51.6
\end{tabular}

DSC measures the excess heat capacity of a solution $\left(C_{p}\right)$ as a function of temperature. When a protein changes its thermodynamic state (e.g., unfolds), a heat capacity change $\left(\Delta_{\mathrm{r}} C_{p}\right)$ is observed. ${ }^{15}$ This change is due to the fact that the heat required to increase the temperature of a solution of unfolded proteins is greater than that required for a solution of folded proteins. $T_{\max }$ is an indicator of thermostability and generally, the higher the $T_{\max }$, the more thermodynamically stable the protein. Integration of the $C_{p}$ versus $T$ curve yields the transition enthalpy $\left(\Delta_{\mathrm{r}} H\right)$ and the shift in the baseline yields the $\Delta_{\mathrm{r}} C_{p}$. The value $\Delta_{\mathrm{r}} H$, calculated from the area under the transition peak, is correlated with the content of the ordered secondary structure within a protein. ${ }^{16}$

Denaturation of the BrILL2 enzyme is thermodynamically irreversible (ESI, $\dagger$ Fig. S11-S13), so all the observed thermodynamic data were obtained from the first scan. The denaturation process is also slightly kinetically controlled (ESI, $\uparrow$ Fig. S11) so the analysis of the thermograms on the basis of equilibrium thermodynamics is ruled out. As can be seen in Table 2 , the $T_{\max }$ for the non-reduced wt enzyme was $56.4{ }^{\circ} \mathrm{C}$. The point mutation Cys139 to Ser did not influence the $T_{\max }$ of the enzyme, while the mutation Cys320 to Ser caused a decrease of the $T_{\max }$ by approximately $3{ }^{\circ} \mathrm{C}$. This suggests that the mutant C320S is less stable in the non-reduced form, compared to the wt and C139S mutant. Studies on similar systems are rather scarce in the literature, and, so far, there are no available data on the representatives of the M20 peptidase family. We compared thermodynamic data of several peptidases with the herein obtained data for BrILL2. Carboxypeptidase B is a globular enzyme, but it is of a somewhat smaller size (procarboxypeptidase B: $45.5 \mathrm{kDa}$ and carboxypeptidase B: $34.5 \mathrm{kDa}$ ) in comparison to BrILL2 (49.8 kDa). DSC analysis revealed similar irreversible thermal denaturation for carboxypeptidase $\mathrm{B}\left(T_{\max }=55-70{ }^{\circ} \mathrm{C}\right)$, but larger $\Delta_{\mathrm{r}} H$ values (500-800 kJ mol $\left.{ }^{-1}\right)$ in comparison to BrILL2 $\left(60-90 \mathrm{~kJ} \mathrm{~mol}^{-1}\right){ }^{17}$ 
Furthermore, procarboxypeptidase A and carboxypeptidase A from porcine pancreas (46.4 $\mathrm{kDa}$ and $34.8 \mathrm{kDa}$, respectively) revealed also irreversible thermal denaturation in a significantly larger temperature span $\left(T_{\max }=40-70{ }^{\circ} \mathrm{C}\right)$, and a $\Delta_{\mathrm{r}} H$ value of approximately $600 \mathrm{~kJ} \mathrm{~mol}^{-1} \cdot{ }^{18}$ Leucine aminopeptidase revealed a $T_{\max }$ almost identical to the herein studied BrILL2 $\left(57 \pm 0.5{ }^{\circ} \mathrm{C}\right)$ and a three-fold higher $\Delta_{\mathrm{r}} H$ value of $80 \pm 0.1 \mathrm{kcal} \mathrm{mol}^{-1}\left(335 \pm 0.4 \mathrm{~kJ} \mathrm{~mol}^{-1}\right) .{ }^{19}$ Thus, the compared enzymes, having similar general functions, and approximately comparable sizes are characterised by similar thermodynamic parameters of denaturation.

All enzymes showed lower $T_{\max }$ values and consequently certain protein destabilization upon adding a reducing agent. The $\Delta_{\mathrm{r}} H$ value for the C320S mutant is significantly lower than that measured for the wt and C139S mutant, in both, polymeric and monomeric forms. These results suggest that both Cys residues contribute to the regulation of enzyme activity through the formation of non-active polymers by disulfide bonds. However, the Cys320 residue seems to be more important in protein stabilization, while Cys139 is directly responsible for the enzyme activity. We attempted to purify BrILL2 in the presence of a reducing agent, i.e. in the monomeric form. However, the purified protein was inactive. This confirmed that BrILL2 is highly unstable in the monomeric form. Werner et al. ${ }^{20}$ reported that the monomeric form of allantoate amidohydrolase is the active form of the enzyme, but is less stable than polymeric forms which is in agreement with our finding. Based on our experimental results, we propose a possible enzyme activity regulation in vivo by dissociation of polymers in the presence of natural reductants. Our hypothesis is that auxin amidohydrolases are active in the monomeric form, but, as such a form is highly unstable, the enzymes have a tendency to stabilize by forming polymers in vivo. To prove the effectiveness of the potential natural reducing agents on the activation of the BrILL2 enzyme, we examined the influence of various naturally occurring reducing agents such as reduced glutathione (GSH), ascorbic acid (AA), and the amino acid Cys on enzyme activity (Table 3). GSH, AA and Cys were as equally potent in the activation of BrILL2 as DTT and $\beta$-mercaptoethanol which are routinely used in the enzyme assay. These results again implicated a lower activity of the C320S mutant in comparison to the wt. Both enzymes were reversibly inactivated in the absence of any reducing agent, while both of them lost activity irreversibly upon alkylation with

Table 3 Specific enzyme activities of BrILL2, wt and mutants ( $\mu$ mol auxin $\mathrm{mg}^{-1} \mathrm{~min}^{-1}$ ) in the presence of various reducing agents. The initial concentration of the substrate IPA-Ala in the reaction mixture was $0.5 \mathrm{mM}$ and the protein concentration was $2.008 \times 10^{-7} \mathrm{M}$. nd - not determined. The values are average \pm SE

\begin{tabular}{llll}
\hline & BrILL2wt & BrILL2C320S & BrILL2C139S \\
\hline No thiol agent & nd & nd & nd \\
DTT $(1 \mathrm{mM})$ & $1.87 \pm 0.19$ & $1.64 \pm 0.67$ & nd \\
$\beta$-MeOH $(1 \mathrm{mM})$ & $1.55 \pm 0.70$ & $1.62 \pm 1.1$ & nd \\
GSH $(1 \mathrm{mM})$ & $1.13 \pm 0.41$ & $0.70 \pm 0.03$ & nd \\
AA $(1 \mathrm{mM})$ & $0.99 \pm 0.66$ & $0.16 \pm 0.07$ & nd \\
Cys $(1 \mathrm{mM})$ & $1.24 \pm 0.85$ & $1.24 \pm 0.51$ & nd \\
I-Acetamide & nd & nd & nd
\end{tabular}

I-acetamide (Table 3). The activity of auxin amidohydrolases could be regulated on demand through redox-switches in the plant cell which include natural reducing agents such as GSH, AA and Cys. Good examples in the plant kingdom are seed proteins that undergo redox changes during development and germination. ${ }^{21}$ Upon synthesis, proteins become oxidized to a more stable disulfide (S-S) state during maturation and drying. Upon germination, the proteins are converted back to the reduced state to facilitate mobilization. The importance of highly conserved Cys residues in the stabilization of protein and redox regulation of activity has also been demonstrated in one type of protein tyrosine phosphatases (PTPs) (Src homology 2 domain containing PTPs (SHPs)). ${ }^{22}$ Furthermore, glycine decarboxylase (P-protein) was also reported as an enzyme regulated by cellular redox homeostasis. ${ }^{23}$ The formation of homodimers by disulfide bonds is subject to regulation by the redox status of the cell and restricts access of the substrate to the active site. Under conditions favoring catalysis, the disulfide bond is broken enabling the opening of an unlocked position of the active site. ${ }^{23}$

\subsection{Role of the conserved Cys139 residue in metal coordination}

2.2.1. Quantitative measurements of $\mathrm{Mn}^{2+}$ in the enzyme active site by HR-ICP-MS and ITC. Our mutagenesis experiments confirmed that Cys139 is crucial for BrILL2 enzyme activity (Table 1). Based on the previous modelling studies, the presence of two $\mathrm{Mn}^{2+}$ ions has been predicted in the active site of BrILL2, and Cys139 as a part of the binding pocket that coordinates metal binding. ${ }^{11}$

Metalloproteins and metalloenzymes that contain binuclear active sites are prevalent in nature. ${ }^{24}$ A structurally similar $(S)$-ureidoglycolate amidohydrolase has been reported to contain two $\mathrm{Mn}^{2+}$ ions in the active site. ${ }^{14}$ In order to experimentally confirm the number of $\mathrm{Mn}^{2+}$ ions bound to the BrILL2 active site, and to investigate whether Cys139 participates in the $\mathrm{Mn}^{2+}$ binding, high resolution inductively coupled plasma mass spectrometry (HR-ICP-MS) and isothermal titration calorimetry (ITC) analyses of BrILL2wt and the C139S mutant were performed.

HR-ICP-MS of the wt and C139S mutant were done in samples following purification (as described in Methods), in samples which were chelated by EDTA and samples which were saturated by $\mathrm{Mn}^{2+}$ after chelation by EDTA. The results showed that the purified BrILL2wt enzyme was slightly saturated with $\mathrm{Mn}^{2+}$ during protein production $\left(\mathrm{Mn}^{2+} /\right.$ enzyme ratio: 0.114$)$. The $\mathrm{Mn}^{2+}$ /apoenzyme ratio was 0.068 , while the $\mathrm{Mn}^{2+}$ /enzyme ratio upon saturation with $\mathrm{Mn}^{2+}$ was 5.4 which was much higher than that expected based on the previous modelling results (ESI, $\dagger$ Table S1).

To confirm these findings, ITC measurements were done by using a multiple injection method. Fig. 3 shows a representative ITC titration profile of BrILL2wt with the $\mathrm{MnCl}_{2} \cdot 4 \mathrm{H}_{2} \mathrm{O}$ (the ITC titration profile of the C139S mutant is shown in Fig. S2, $\mathrm{ESI} \dagger$ ). The reverse titration profile of $\mathrm{MnCl}_{2} \cdot 4 \mathrm{H}_{2} \mathrm{O}$ with BrILL2wt is shown in Fig. S4, ESI $\dagger$. The blank titration (titration of $\mathrm{MnCl}_{2} \cdot 4 \mathrm{H}_{2} \mathrm{O}$ into the buffer solution) (ESI, $\dagger$ Fig. S3) was 


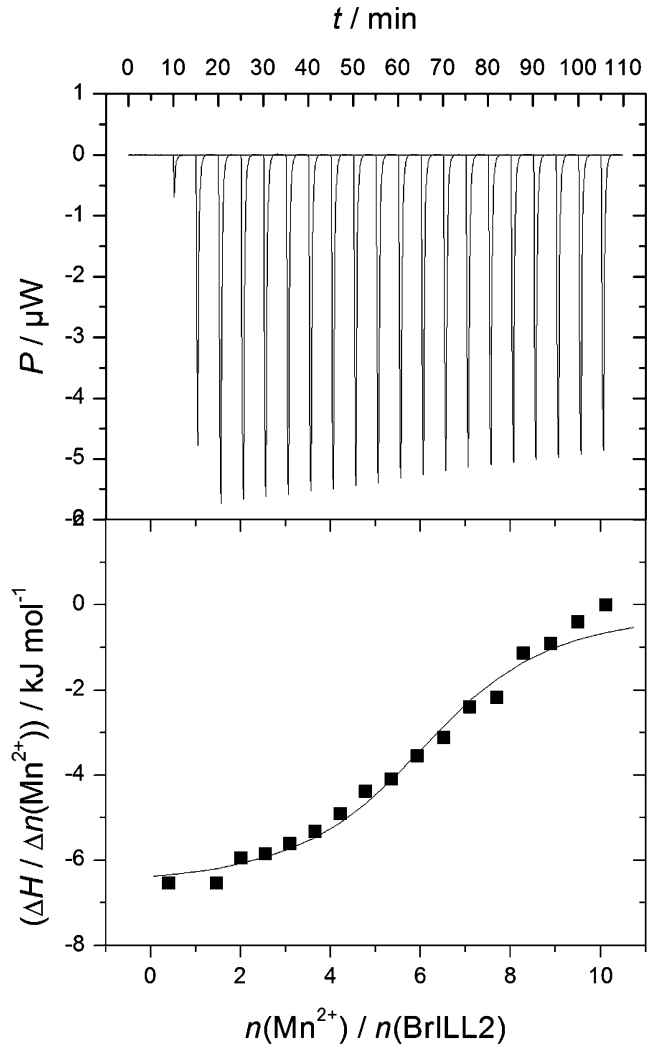

Fig. 3 Representative ITC titration profile of the BrILL2wt enzyme $(5 \times$ $\left.10^{-6} \mathrm{~mol} \mathrm{dm}{ }^{-3}\right)$ with $\mathrm{MnCl}_{2} \cdot 4 \mathrm{H}_{2} \mathrm{O}\left(2.5 \times 10^{-4} \mathrm{~mol} \mathrm{dm}^{-3}\right)$.

subtracted from each ITC titration (titration of BrILL2wt with $\mathrm{MnCl}_{2} \cdot 4 \mathrm{H}_{2} \mathrm{O}$ ). Each of the peaks in the figures corresponds to a single injection. The areas under these peaks were determined by integration to yield the associated injection heats, which were plotted against the respective molar ratios. The data points reflect the experimental injection heats, while the solid lines reflect calculated fits of data. Fitting procedures were performed using a model with one set of sites. The equilibrium constant, binding stoichiometry, reaction enthalpy change, entropy contribution, and Gibbs energy change obtained from the calorimetric data are summarized in Table 4. It is noteworthy that the results obtained from titration of BrILL2wt with $\mathrm{MnCl}_{2}$ (Table 4; $\left.N=5.6 \pm 0.3 ; \log K_{\mathrm{a}}=5.5 \pm 0.1 ; \Delta_{\mathrm{r}} G=-31.6 \pm 0.8 \mathrm{~kJ} \mathrm{~mol}^{-1}\right)$ and reverse titration (Fig. S4 (ESI $\dagger$ ), $N=5.6 \pm 0.4 ; \log K_{\mathrm{a}}=5.4 \pm 0.2$; $\Delta_{\mathrm{r}} G=-30.7 \mathrm{~kJ} \mathrm{~mol}^{-1}$ ) are almost identical. The results show no significant differences in titration profiles of binding $\mathrm{MnCl}_{2}$ to BrILL2wt (Fig. 3) and the C139S mutant (ESI, $\dagger$ Fig. S2). In general, the binding of $\mathrm{MnCl}_{2}$ to BrILL2wt and the BrILL2C139S mutant is favored by small negative enthalpies and large positive entropy changes. For example, the binding of $\mathrm{Mn}^{2+}$ to the TroR enzyme was also reported as an entropy-driven process. ${ }^{25}$ The fitting of the experimental data revealed the binding stoichiometry of $\mathrm{Mn}^{2+} /$ enzyme (wt or C139S) in the range of 5-6, which is in agreement with the HR-ICP-MS results. The enzymes studied here had a His-tag (hexa histidine-tag) for purification reasons, and the His-tag is well known to bind not only $\mathrm{Ni}^{2+}$ cations, but other cations as well. ${ }^{26,27}$ Therefore, we also performed ITC experiments of a single His-tag with $\mathrm{MnCl}_{2}$, which resulted in surprisingly high binding constants and a $\mathrm{Mn}^{2+} /$ His-tag stoichiometry equal to $2: 1$ (Table 4 ). The results obtained suggest that in $\mathrm{MnCl}_{2}$-enzyme titrations two $\mathrm{Mn}^{2+}$ ions are located in the active site of the enzyme, two are bound to the His-tag, and the rest (1 or 2) are electrostatically bound to the non-specific sites along the enzyme. Further modelling analysis confirmed this hypothesis (see Section 2.2.3).

2.2.2. Stability examination upon metal binding by CDS and DSC. Based on ITC and HR-ICP-MS data, it is obvious that the point mutation Cys139 to Ser does not affect the binding of $\mathrm{Mn}^{2+}$ into the active site. To investigate whether the same mutation influences the conformational changes upon metal binding, CDS and DSC measurements were done upon $\mathrm{MnCl}_{2}$ titration of BrILL2wt and the BrILL2C139S mutant. DSC data show negligible changes in the $T_{\max }$ after the binding of $\mathrm{Mn}^{2+}$ to both enzymes, which also means that there are non-significant conformational changes upon binding (Table 5). The results of CD spectropolarimetry also confirmed non-significant changes in secondary structures upon metal binding which is in agreement with DSC data (data not shown). Thus, the loss of activity upon Cys to Ser replacement in the BrILL2 enzyme was not caused by potential conformational perturbations upon metal binding.

2.2.3. The role of the Cys139 residue revealed by molecular modelling. The calorimetric, kinetics, and spectroscopic experimental data revealed that the Cys139 to Ser mutation does not significantly influence the BrILL2 structure and metal ion affinity, but causes activity loss. However, the details of the 3-D structure of BrILL2 variants are out of the scope of these

Table 5 DSC data for BrILL2wt, the Mn-BrILL2wt complex, BrILL2C139S and the Mn-BrlLL2C139S complex obtained during heating from 25 to $90{ }^{\circ} \mathrm{C}$ at a rate of $1^{\circ} \mathrm{C} \mathrm{min}^{-1}$. The values are average $\pm \mathrm{SE}$

\begin{tabular}{llll}
\hline Enzyme & $T_{\max }{ }^{\circ} \mathrm{C}$ & $\Delta_{\mathrm{r}} H / \mathrm{kJ} \mathrm{mol}^{-1}$ & $\Delta_{\mathrm{r}} S / \mathrm{J} \mathrm{K}$ \\
\hline BrILL2wt & $56.5 \pm 0.1$ & $54.6 \pm 6.0$ & $165.7 \pm 18.1$ \\
Mn-BrILL2Wt complex & $56.2 \pm 0.2$ & $73.9 \pm 19.4$ & $224.5 \pm 58.9$ \\
BrILL2C139S & 56.8 & $93.8 \pm 2.1$ & $284.3 \pm 6.5$ \\
Mn-BrILL2C139S complex & $57.2 \pm 0.3$ & $46.7 \pm 2.6$ & $141.3 \pm 7.8$
\end{tabular}

Table 4 Data observed during fitting with a model with one set of sites for ITC titration of BrILL2, wt and C139S mutant, as well as the His-tag with $\mathrm{MnCl}_{2} \cdot 4 \mathrm{H}_{2} \mathrm{O}$. The values are average $\pm \mathrm{SE}$

\begin{tabular}{|c|c|c|c|c|c|c|}
\hline Enzyme & $N$ & $\log K_{\mathrm{a}}$ & $\Delta_{\mathrm{r}} H / \mathrm{kJ} \mathrm{mol}^{-1}$ & $\Delta_{\mathrm{r}} S / \mathrm{J} \mathrm{K}^{-1} \mathrm{~mol}^{-1}$ & $T \Delta_{\mathrm{r}} S / \mathrm{kJ} \mathrm{mol}^{-1}$ & $\Delta_{\mathrm{r}} G / \mathrm{kJ} \mathrm{mol}^{-1}$ \\
\hline BrILL2wt & $5.6 \pm 0.3$ & $5.5 \pm 0.1$ & $-6.2 \pm 0.6$ & $85.1 \pm 3.5$ & 26.3 & $-31.1 \pm 0.8$ \\
\hline BrILL2C139S & $5.5 \pm 0.2$ & $5.6 \pm 0.1$ & $-8.6 \pm 0.4$ & 78.2 & 23.3 & -31.9 \\
\hline His-tag & 2.0 & $4.6 \pm 0.1$ & $1.5 \pm 0.1$ & $92.2 \pm 0.8$ & 27.5 & $-26.1 \pm 0.3$ \\
\hline
\end{tabular}


experimental methods. In order to provide an insight into the structure and dynamics of the systems we performed a series of long MD simulations. The simulations revealed possible metal binding sites and enabled us to propose possible reasons for the inactivation of the C139S mutant.

$M D$ simulations of the ligand free enzyme: the protein structure and the metal binding site. $200 \mathrm{~ns}$ long MD simulations of the native BrILL2 and the BrILL2C139S mutant, with serine in two different protonation states, Cys139Ser and Cys139Ser ${ }^{-}$, with and without $\mathrm{Mn}^{2+}$ ions bound into the assumed active site were performed. The results obtained by the MD simulations are in agreement with the experimental DSC and CD data which suggested that neither the presence of the manganese ions nor the Cys139 to Ser mutation affects the protein 3D structure. The presence of the metal ions has no influence on the overall protein structure during the MD simulations, and no significant differences in the structure and flexibility/stability of the wt protein and the mutant were traced over $200 \mathrm{~ns}$ of MD simulations in solvent at room temperature (Fig. 4, and ESI, $\dagger$ Fig. S5). Similarly, the active site architecture, especially the surrounding of the metal ion at position 2, i.e. the more buried ion $\left(\mathrm{Mn}^{2+}\right.$ at position 1 is closer to the active site entrance than $\mathrm{Mn}^{2+}$ at position 2, and so is more solvated) was not affected by the Cys139 to Ser mutation (ESI, $\dagger$ Fig. S6). However, while in the mutant with the deprotonated serine $139\left(\mathrm{C}_{3} \mathrm{~S}^{-}\right)$the position of manganese ions in the active site does not differ significantly from their position in the wild type enzyme and their average distance is about $4 \AA$ during all 200 ns MD simulations; in the variant with neutral serine, C139S, the metal ions moved away from each other during the simulations and after 200 ns they were about 7 A apart from each other (ESI, $\dagger$ Fig. S7 and Table S2).

The other possible metal ion binding sites were investigated by placing four ions at the minimal energy positions at the protein surface and performing 22 ns long MD simulations. During the simulations only one of the ions from the protein surface, the ion at position 3 near Glu357 (average distance $2.63 \AA$ ) and Glu358 (average distance $2.53 \AA$ A) (Fig. 1) remained anchored to the protein. The two $\mathrm{Mn}^{2+}$ ions in the enzyme active site together with one $\mathrm{Mn}^{2+}$ ion at the protein surface nicely correlate with the experimentally determined number of $\mathrm{Mn}^{2+}$ ions (3.4) that bind to the BrILL2 enzyme without a His-tag, the wild type and the C139S mutant.

MD simulations of the BrILL2-IPA complexes. Since the metal cations are constituents of the auxin amidohydrolase active site, their significantly different coordination in the C139S variant is a direct explanation of catalytic inactivity of this mutant. In order to elucidate possible reasons for the loss of the enzymatic activity of the C139S mutant we performed MD simulations of BrILL2 complexed with IPA-Ala, for which experiments have shown that it is the most favored BrILL2 substrate. ${ }^{11}$ For each system, the solvated complexes with the wt protein and the C139S mutant, 200 ns of simulations was accomplished.

Within the wt protein we identified two slightly different ligand binding modes, BM1 and BM2 (ESI†, Fig. S8 and S9).
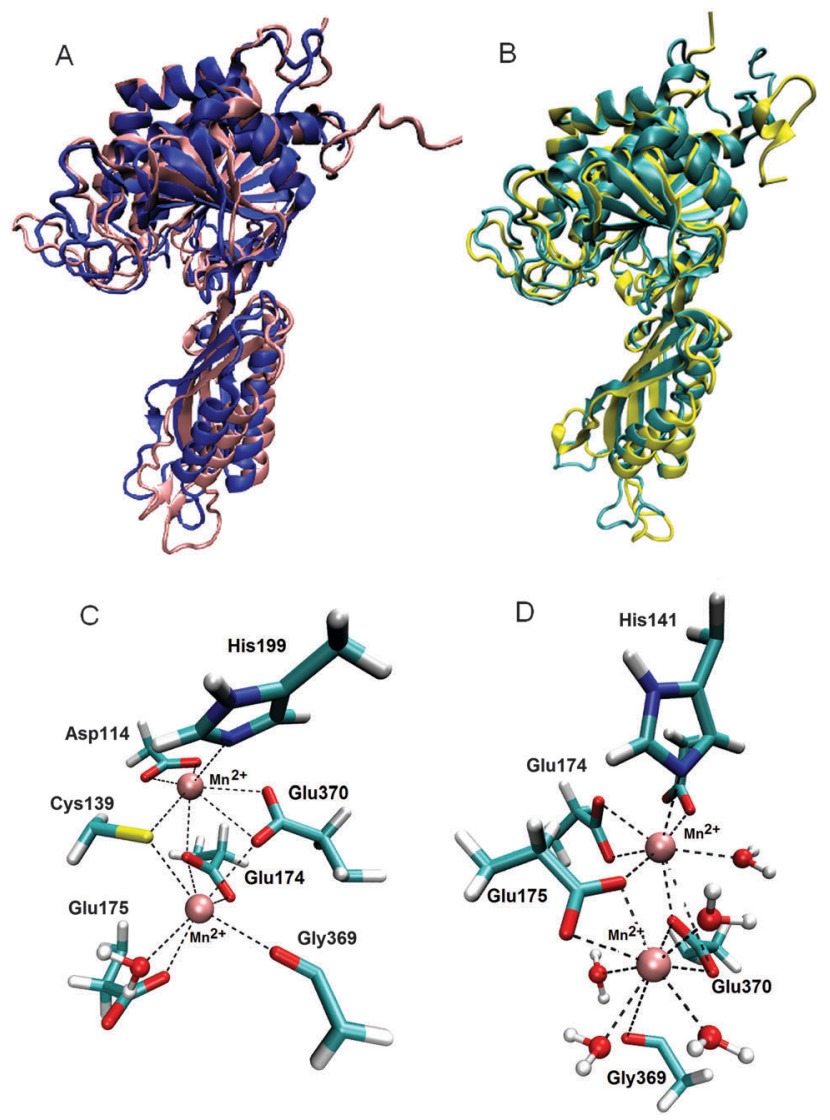

Fig. 4 (A) Alignment of the BrILL2wt protein structures obtained after MD simulations in the presence (pink) and absence of $\mathrm{Mn}^{2+}$ ions (blue). (B) Alignment of the mutated $\left(\mathrm{C}_{139 \mathrm{~S}^{-}}\right)$structures obtained after $\mathrm{MD}$ simulations in the presence (yellow) and absence of $\mathrm{Mn}^{2+}$ ions (cyan). (C) $\mathrm{Mn}^{2+}$ surrounded by the wt protein. All residues (side chains) and water molecules within $3 \AA$ of metal ions are displayed. The lower $\mathrm{Mn}^{2+}$ ion $\left(\mathrm{Mn}^{2+} 1\right)$, the metal ion which is closer to the active site entrance, is surrounded (coordinated) by Cys139, Glu174, Glu175, Gly369, Glu370 and one water molecule. The upper $\mathrm{Mn}^{2+}$ ion $\left(\mathrm{Mn}^{2+} 2\right)$ is coordinated by Asp114, Cys139, Glu174, His199 and Glu370. (D) $\mathrm{Mn}^{2+}$ surrounded by the mutated protein

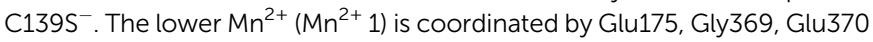
and four water molecules. The upper $\mathrm{Mn}^{2+}$ ion $\left(\mathrm{Mn}^{2+} 2\right)$ is coordinated by Asp114, His141, Glu174, Glu175, Glu370 and two water molecules, see ESI,† Table S3.

In the mutated complexes the orientation of the substrate differs from the orientations determined in the wt protein (ESI, $\dagger$ Fig. S8 and S9). In all complexes, IPA-Ala coordinates either one or both of the $\mathrm{Mn}^{2+}$ ions during the simulations (Fig. 5 and ESI, $\dagger$ Table S3, Fig. S8 and S9).

According to the MM_PBSA calculations performed at the trajectories generated during the last $8 \mathrm{~ns}$ (of the total $200 \mathrm{~ns}$ of MD simulations in water) the complexes between the wt protein and IPA-Ala are more stable than the mutated C1395 ${ }^{-}$-IPA-Ala (ESI, $\dagger$ Table S4).

In the most stable BrILL2-IPA-Ala binding mode (BM1), both the substrate carbonyl and carboxyl groups coordinate the $\mathrm{Mn}^{2+}$ ion closer to the active site entrance, position 1 (ESI, $\dagger$ Table S5). The indole ring is stabilized by the hydrophobic interactions with Arg203, Leu217, Ile366 and Phe385 (weak face to edge type of 
A

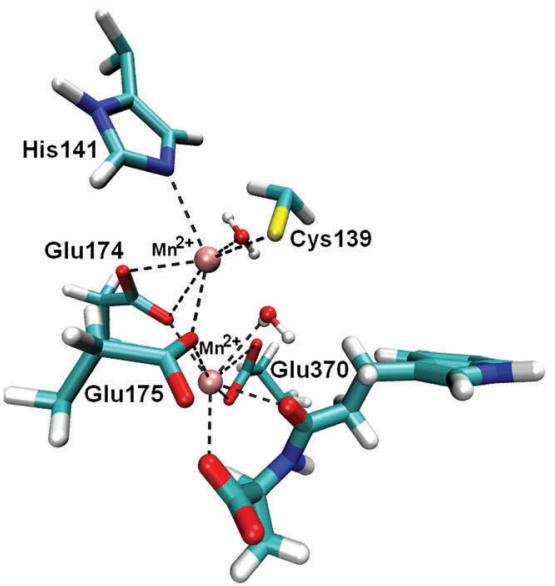

B

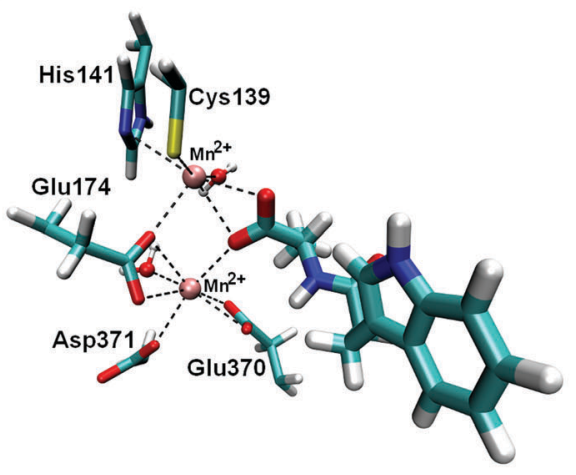

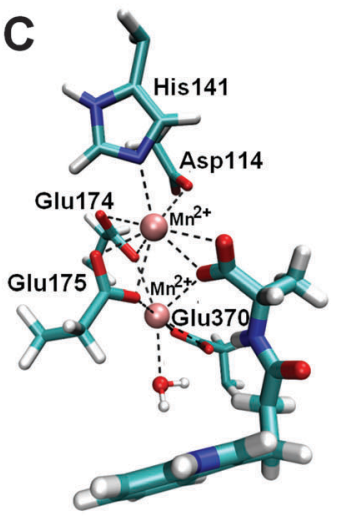

Fig. 5 Binding sites of BrILL2-IPA-Ala complexes obtained during MD simulations. Two manganese ions are shown as violet spheres. IPA-Ala is shown in a thicker sticks representation. For simplicity only side chains of amino acids are shown. (A) Complex BrILL2wt-IPA-Ala, binding mode 1 (BM1). The distance between IPA-Ala and $\mathrm{Mn}^{2+}$ is approximately $2.5 \AA$ (shown as dashed lines). (B) Complex BrILL2wt-IPA-Ala, binding mode 2 (BM2). The distance between IPA-Ala and $\mathrm{Mn}^{2+}$ is approximately $2.6 \AA$ (shown as dashed lines). (C) Complex BrILL2C139S ${ }^{-}-$IPA-Ala. Distance between IPA-Ala and Mn ${ }^{2+}$ is approximately $2.6 \AA$ (shown as dashed lines). For details of coordination see the ESI, $\uparrow$ Table S3.

stacking interaction) (ESI, $\dagger$ Fig. S9). The substrate NH group of the peptide bond is stabilized by the hydrogen bond to the Gly369 carbonyl, while the methyl group is in the neighbourhood of the hydrophobic Leu177 side chain. The water molecules in the active site are frequently replaced by the water molecules from the bulk; however, for a few of them the exchange ratio is lower than for the others pointing to their better stabilization (ESI, $\dagger$ Table S6). One of such resistant water molecules was found close to the peptide carbonyl of IPA-Ala. This water molecule could be activated either by the carboxyl group of Glu175 or by the carboxyl group of the substrate itself.

In the BM2, IPA-Ala coordinates both $\mathrm{Mn}^{2+}$ ions with its carboxyl group. The indole ring is stabilized by hydrophobic interactions with Arg203 and Leu217. Besides, the carbonyl oxygen of Leu217 occasionally interacts with the indole $\mathrm{NH}$ group during the simulations (ESI, $\dagger$ Fig. S9 and Table S5). Thr201 also participates in the indole ring stabilization. The hydrophobic part of the propyl group is stabilized by the side chain of Leu217, and its methyl group with the Ala397 methyl. The NH group of the peptide bond is stabilized by the Glu370 carboxyl; besides this carboxyl group forms a strong $\mathrm{H}$-bond with a water molecule close to the substrate carbonyl. It might be that Glu370 activates this water molecule which then performs the nucleophilic attack to the carbonyl carbon. In the next step, Glu370 donates the $\mathrm{H}$ from the activated water to the substrate $\mathrm{NH}$ group which is additionally stabilized with the Gly369 oxygen.

In the $\mathrm{C}_{139 \mathrm{~S}^{-}}$mutant, IPA-Ala coordinates both $\mathrm{Mn}^{2+}$ ions with its carboxyl group (ESI, $\uparrow$ Fig. S9 and Table S5). The indole ring is stabilized by the hydrophobic interactions with Phe447 and Ile366, while Gly369 carbonyl interacts with the indole hydrogen H1. Despite significant fluctuations, the Arg203 side chain constantly approaches the substrate during MD simulation (ESI, $\dagger$ Fig. S10). In the final structure, it interacts electrostatically with the substrate carbonyl group and hinders nucleophilic attack of water molecules required for the enzymatic reaction.

\section{Experimental}

\subsection{Materials}

Commercial, analytical grade chemicals and solvents were used if not stated otherwise.

The plasmid pTrcHis2-Topo containing the previously cloned cDNA corresponding to the BrILL2 protein (called simply pBrILL2) ${ }^{28}$ was used for the expression of the wt enzyme and as a template for generating the mutants.

The bacterial strain $E$. coli XL-10 Gold (Stratagene, La Jolla, CA, USA) was used for plasmid propagation, and E. coli BL21Codon-Plus (DE3)-RIL ${ }^{+}$(Stratagene, La Jolla, CA, USA) was used for the synthesis of the BrILL2wt protein and the mutants BrILL2C139S, BrILL2C320S, and BrILL2C239,320S. The substrate IPA-Ala was synthesized as previously published. ${ }^{9}$

\subsection{Site-directed mutagenesis and sequencing}

Site-directed mutagenesis was performed on the recombinant plasmid pBrILL2. Point mutations of the BrILL2 gene C139S and C320S were carried out using the QuickChange II XL SiteDirected Mutagenesis kit (Stratagene, LaLoya, CA, USA) by using the corresponding pair of primers custom synthesized by Invitrogen (USA). Primers for C139S mutation:

Forward: 5'-GGTAAAATGCACGCTTCTGGACACGACCG-3' and Reverse: $5^{\prime}$-CCGTCGTGTCCAGAAGCGTGCATTTTACC- $3^{\prime}$; and for C320S mutation:

Forward: 5'-CGGATGCATTGGACCTCTGAACTGTTGC-3' and Reverse: $5^{\prime}$-GCAACAGTTCAGAGGTCCAATGCATCCG-3' .

The double mutant C139,320S was generated by using the mutant plasmid pBrILL2C139S already obtained and the corresponding pair of primers for introducing the C320S mutation.

The DNA sequences of the final constructs were analyzed using an automated sequence analyser "ABI PRISM_3100-Avant Genetic Analyzer" (Applied Biosystem, USA), using a ABI PRISM 
BigDye Terminator v3.1 Ready Reaction Cycle Sequencing Kit, and commercial $\mathrm{T} 7$ forward and $\mathrm{T} 7$ reverse primers.

\subsection{Protein synthesis and purification}

The recombinant proteins of BrILL2, wt and mutants were produced by heterologous expression in the $E$. coli strain BL21(DE3)RIL ${ }^{+}$as previously described. ${ }^{11}$ For the protein purification and dialysis, as well as subsequent analysis, all buffers were prepared in high purity Milli-Q water obtained from a Millipore purification system (resistivity less than $18 \mathrm{M} \Omega \mathrm{cm}$ ). To isolate recombinant proteins, the bacterial pellet was resuspended in buffer $(50 \mathrm{mM}$ phosphate or $50 \mathrm{mM}$ Tris buffer, $300 \mathrm{mM}$ $\mathrm{NaCl}, 10 \mathrm{mM}$ imidazole, $50 \mu \mathrm{g} \mathrm{mL}^{-1} \mathrm{PMSF}, 1 \mathrm{mg} \mathrm{mL}{ }^{-1}$ lysozyme, $0.1 \%$ Triton $\mathrm{X}-100, \mathrm{pH} 8.0$ ) and then $10 \mathrm{~mL}$ per $\mathrm{g}$ of pellet, following incubation on ice for $30 \mathrm{~min}$, was frozen in liquid nitrogen and thawed. The freeze-thaw cycle was repeated two times. The resulting lysate was supplemented with $10 \mu \mathrm{g}$ DNAse I, (Boehringer Mannheim $\mathrm{GmbH}$ ), incubated at room temperature (at approximately $23{ }^{\circ} \mathrm{C}$ ) for 20 minutes and centrifuged $(10000 \mathrm{~g}, 40$ minutes, $4{ }^{\circ} \mathrm{C}$ ). proteins were purified by affinity chromatography on a Ni-NTA agarose column according to the manufacturer's instructions (Qiagen). The proteins recovered were quantified according to Bradford's method and subsequently analyzed by SDS-PAGE (12.5\% acrylamide). ${ }^{29}$ Fractions of high purity were pooled and dialyzed overnight at $4{ }^{\circ} \mathrm{C}$ against $50 \mathrm{mM}$ Tris, $300 \mathrm{mM} \mathrm{NaCl}(\mathrm{pH} 8.0)$ to remove the excess of imidazole. Further buffer exchange was performed as described below for the ICP-MS and calorimetric analysis. The dialyzed protein was shortly stored at $4{ }^{\circ} \mathrm{C}$ for further studies.

\subsection{Circular dichroism spectropolarimetry (CDS)}

To investigate the secondary structure of the enzyme mutants obtained in comparison to the wt, CD spectra of recombinant proteins were recorded on a Jasco J-815 CD spectropolarimeter with automatic temperature control using a quartz cuvette of $0.1 \mathrm{~mm}$ path length. Enzyme samples were prepared for CD measurements by exchange into $50 \mathrm{mM}$ phosphate buffer, $\mathrm{pH}$ 8.0. The protein concentrations used were from 0.31 to $0.39 \mathrm{mg} \mathrm{mL}{ }^{-1}$. The $\mathrm{CD}$ spectra were collected in the 190-300 $\mathrm{nm}$ range, and analyzed for the protein secondary structure as previously described. ${ }^{30}$

\subsection{Western blotting}

For the analysis of protein polymerization capacity, Western blotting of wt and mutant proteins were performed. The purified proteins, unreduced and reduced by $\beta$-mercaptoethanol, were separated by SDS-PAGE in a $4-20 \%(\mathrm{w} / \mathrm{v})$ polyacrylamide gel. Proteins were then transferred to a polyvinylidene difluoride (PVDF, Millipore, USA) membrane. Following blocking with $5 \%(\mathrm{w} / \mathrm{v})$ non-fat dry milk (Carl Roth, Germany), blots were incubated in the penta-His antibody (Qiagen), using an antibody/ buffer ratio of $1: 2000$. Horse radish peroxidase (HRP)-conjugated goat anti-mouse IgG (Santa Cruz Biotechnology) was employed as the second antibody in a 1:10000 ratio to the buffer, and chemiluminescence detection was performed using luminol as a substrate and $p$-coumaric acid as an enhancer according to the method reported by Mruk and Cheng. ${ }^{31}$

\subsection{Enzyme assay}

Enzyme reactions were run in $100 \mathrm{mM}$ Tris- $\mathrm{HCl} \mathrm{pH} 8.0$ in the presence of $0.2 \mathrm{mM} \mathrm{MnCl}_{2}$ and $1 \mathrm{mM}$ DTT at $37{ }^{\circ} \mathrm{C}$ using $0.5 \mathrm{mM}$ IPA-Ala as a substrate IPA-Ala. The effect of the additional reducing agents ( $\beta$-mercaptoethanol, reduced glutathione, cysteine, and ascorbic acid) was also examined at a concentration of $1 \mathrm{mM}$. To examine the effect of alkylation of Cys residues on enzyme activity, proteins were also incubated with I-acetamide according to Lundblad's method ${ }^{32}$ prior to activity measurements. Enzyme kinetics were determined for BrILL2, wt and C320S, by calculating initial reaction rates $\left(v_{0}\right)$ in the concentration range of the substrate (IPA-Ala) 0.1-2.0 $\mathrm{mM}$. The progress of the cleavage reaction was monitored by HPLC according to the method reported by Savić et al. ${ }^{11}$

\subsection{High resolution inductively coupled plasma mass spectrometry (HR-ICP-MS)}

For the ICP-MS analysis of the BrILL2 protein, the protein was prepared in three forms: (1) enzyme immediately after purification by affinity chromatography, with a buffer exchanged 3 times into $50 \mathrm{mM}$ Tris-HCl, pH 8.0; (2) an apoenzyme obtained by a 3 hour dialysis in $10 \mathrm{mM}$ EDTA, $50 \mathrm{mM}$ Tris, $100 \mathrm{mM} \mathrm{NaCl}$, pH 8.0, which was afterwards dialyzed as in (1); and (3) a holoenzyme prepared by firstly chelating the non-specifically bound metal ions with a 3 hour dialysis in $10 \mathrm{mM}$ EDTA, $50 \mathrm{mM}$ Tris, $100 \mathrm{mM} \mathrm{NaCl}, \mathrm{pH}$ 8.0, following 3 times exchange into $50 \mathrm{mM}$ Tris, $100 \mathrm{mM} \mathrm{NaCl}, \mathrm{pH} 8.0$, and then saturated by $1 \mathrm{mM} \mathrm{MnCl}_{2}$ in the same dialysis buffer. Excess of $\mathrm{MnCl}_{2}$ was removed by further exchanging the buffer 3 times into $50 \mathrm{mM}$ Tris- $\mathrm{HCl}$, pH 8.0. All containers used in ICP-MS were previously cleaned by soaking for several days in $10 \% \mathrm{HNO}_{3}$ solution and rinsed with Milli-Q water before use. The measurements of ${ }^{55} \mathrm{Mn}$ were performed in the medium resolution mode on a high-resolution inductively coupled plasma mass spectrometer (HR ICPMS Element 2, Thermo Finnigan, Germany) equipped with an autosampler ESI-a SC-2 DX FAST (Elemental Scientific, USA). The typical instrumental conditions and measurement parameters used throughout the work were reported previously. ${ }^{33}$ External calibration was performed using standard solutions prepared from multielement stock standard solutions for trace elements (Analitika, Czech Republic) in which a single element standard solution of U (Aldrich, USA) was added.

\subsection{Isothermal titration calorimetry (ITC)}

To study the metalation of BrILL2 with $\mathrm{Mn}^{2+}$ ions by ITC and DSC, the protein solution obtained as in Section 3.3 was further dialyzed to remove any unbound metal ions for $3 \mathrm{~h}$ with $10 \mathrm{mM}$ EDTA, $50 \mathrm{mM}$ Tris-HCl, $100 \mathrm{mM} \mathrm{NaCl}, \mathrm{pH} 8.0$ and the removal of EDTA was achieved by exchanging the dialysis buffer 3 times into $50 \mathrm{mM}$ Tris- $\mathrm{HCl}, \mathrm{pH} 8.0$ and 3 times into $50 \mathrm{mM}$ cacodylate, $\mathrm{pH}$ 7.4. In order to examine metal binding to the wt and C139S mutant, isothermal titration calorimetry (ITC) experiments were performed on a MicroCal VP-ITC microcalorimeter (MicroCal, Inc., Northampton, MA, USA). Origin 7.0 software, supplied by the manufacturer was used for data analysis. The reference cell 
was filled with ultrapure water. In the experiments, one aliquot of $2 \mu \mathrm{L}$ and 28 aliquots of $10 \mu \mathrm{L}$ of the compound $\mathrm{MnCl}_{2}$ $\left(c=2.5 \times 10^{-4} \mathrm{~mol} \mathrm{dm}^{-3}\right)$ were injected from a rotating syringe (307 rpm) into the isothermal cell, equilibrated at $25.0{ }^{\circ} \mathrm{C}$, containing $1.4406 \mathrm{~mL}$ of enzyme $\left(c=5 \times 10^{-6} \mathrm{~mol} \mathrm{dm}^{-3}\right)$.

The spacing between each injection was in the range 240-300 s. The initial delay before the first injection was $600 \mathrm{~s}$ in all experiments. All solutions used in ITC experiments were degassed prior to use under vacuum ( $0.64 \mathrm{bar}, 10 \mathrm{~min})$ to eliminate air bubbles.

Microcalorimetric experiment directly gave three parameters: reaction enthalpy change $\left(\Delta_{\mathrm{r}} H\right)$, binding constant $\left(K_{\mathrm{a}}\right)$ and stoichiometry $(N)$. The value of $\Delta_{\mathrm{r}} G$ was calculated from the binding constant $\left(\Delta_{\mathrm{r}} G=-R T \ln K\right)$ and the reaction entropy change was calculated from the binding enthalpy and Gibbs energy $\left(\Delta_{\mathrm{r}} S=\left(\Delta_{\mathrm{r}} H-\Delta_{\mathrm{r}} G\right) / T\right)$.

\subsection{Differential scanning calorimetry (DSC)}

Differential scanning calorimetry (DSC) was used to investigate the melting temperature of the BrILL2wt enzyme and the mutants using the instrument Nano DSC from TA Instruments. The DSC scans were obtained against a blank Na-cacodylate buffer $(\mathrm{pH}=8.0)$ from $10{ }^{\circ} \mathrm{C}$ to $100{ }^{\circ} \mathrm{C}$ at heating rates of $1{ }^{\circ} \mathrm{C} \mathrm{min}{ }^{-1}$ and $2{ }^{\circ} \mathrm{C} \min ^{-1}$. The corresponding baseline (buffer-buffer) scans were subtracted from the unfolding/folding scans prior to their normalization and analysis. In stability experiments under nonreducing and reducing conditions, the protein concentrations were in the range $0.2-0.5 \mathrm{mg} \mathrm{mL} \mathrm{m}^{-1}$. Monomeric forms of proteins were measured upon addition of $5 \mathrm{mM} \beta$-mercaptoethanol. To examine the metal binding effect, the DSC scans were measured for proteins: BrILL2wt enzyme (0.25-0.5 $\left.\mathrm{mg} \mathrm{mL}^{-1}\right)$, Mn-BrILL2wt complex (0.2-0.4 $\left.\mathrm{mg} \mathrm{mL}^{-1}\right)$, mutant BrILL2C139S (0.25 $\left.\mathrm{mg} \mathrm{mL}^{-1}\right)$ and Mn-BrILL2C139S complex $\left(0.20 \mathrm{mg} \mathrm{mL}^{-1}\right)$.

\subsection{Molecular modelling methods}

The initial systems for our computational study were derived from the previously constructed and studied models. ${ }^{11}$ The 3D protein structure was obtained by homology modelling using the X-ray structure of the IAA-amino acid hydrolase from Arabidopsis thaliana, AtILL2 (pdbs: 1XMB and 2Q43) ${ }^{12,13}$ as a template, and the initial position of metal ions was based on the position of the manganese ions in the recently determined structure of amidohydrolase, SACOL0085, from methicillin-resistant Staphylococcus aureus (pdb: 4EWT). ${ }^{34}$ Both of the mentioned hydrolases belong to the M20 family. The amino acid sequence identity between AtILL2 and BrILL2 is 76\%, while the identity between SACOL0085 and BrILL2 is $34 \%$. The structure of $S$. aureus SACOL0085 amidohydrolase possesses two manganese ions in the active binding site, so we used it for creating the active site of BrILL2. We performed molecular modelling studies of the ligand free enzyme, wild type and the C139S mutants, in the presence and absence of manganese ions. The wild type protein (the van der Waals parameters are shown in the ESI, $\dagger$ Table S7) and two C139S mutants with different protonation states of the serine side chain (neutral and deprotonated) were simulated for $200 \mathrm{~ns}$ each. The mutants were built from the equilibrated wild type structure by replacing Cys139 with Ser, either neutral (C139S), MUT1 or deprotonated $\left(\mathrm{C139S}^{-}\right)$, MUT2. Since the parameters for the deprotonated Ser were not available, we built them using the AMBER14 $4^{35}$ module antechamber combined with semiempirical AM1 calculations. In order to find out how manganese ions influence the protein structure, we performed molecular dynamic simulations (200 ns) of the wild type (WT) and mutated C139S enzymes with and without the $\mathrm{Mn}^{2+}$ ions in the enzymatic binding site. Furthermore, the other possible stable metal ion sites at the protein surface were searched. For this purpose, the four $\mathrm{Mn}^{2+}$ ions were placed in the minimal energy positions at the protein surface and their behaviour during 22 ns-long MD simulations was investigated.

In order to find out possible reasons for inactivity of the C139S mutant, the BrILL2-IPA-Ala complex was studied as well by molecular modelling. For this purpose, two initial orientations of IPA-Ala in the active site of the wild type enzyme were simulated for $200 \mathrm{~ns}$ each and the binding free energies were calculated. The complex with the mutated C139S enzyme was constructed using the energetically more favourable ligand binding mode and the complex was also simulated for $200 \mathrm{~ns}$. The initial orientation of the substrate was based on the previously studied and reported models of the complex. ${ }^{11}$

The parameters for the ligand IPA-Ala were derived using antechamber and parmchk modules of AMBER14. ${ }^{35}$

Parameterization was accomplished within the general AMBER force field GAFF, AMBER ff12SB ${ }^{36}$ (ligand free enzyme) and $\mathrm{ff}_{14 \mathrm{SB}^{37}}$ (complexes). Each of the built complexes and the ligand free enzyme variants was placed in an octahedral box filled with the TIP3P type water molecules. ${ }^{38}$ A water buffer of $11 \AA$ was used. $\mathrm{Na}^{+}$ions were used for the system neutralization. The solvated complexes were geometry optimized using the steepest descent and conjugate gradient methods, 2500 steps of each. After optimization the systems were equilibrated for $0.6 \mathrm{~ns}$ in three steps. During each of the $0.2 \mathrm{~ns}$ long steps the temperature was increased by $100 \mathrm{~K}$. The equilibrated systems were subjected to productive molecular dynamic (MD) simulations at constant temperature and pressure ( $300 \mathrm{~K}, 1 \mathrm{~atm})$. During the first 2 ns of MD simulations the time step was 1 fs and after that $2 \mathrm{fs}$ and the temperature was kept constant by using Langevin dynamics with a collision frequency of $1 \mathrm{ps}^{-1}$. Simulations were performed using periodic boundary conditions (PBCs) by the AMBER14 program pmemd. The long range electrostatic interactions were calculated using the particle mesh Ewald (PME) method and a cut-off distance of $11 \AA$ for the pairwise interactions in the direct space. The binding free energies were calculated using the molecular mechanics Poisson-Boltzmann surface area $(\mathrm{MM}-\mathrm{PBSA})^{39}$ approach as implemented in AMBER12. ${ }^{40,41}$

\section{Conclusions}

Based on the experimental and molecular modelling research, we confirmed that two conserved Cys residues (Cys139 and Cys320) of Brassica rapa auxin amidohydrolase BrILL2 play important roles in the regulation of enzyme activity and enzyme stabilization. 
The Cys320 residue is mainly responsible for protein stabilization through participation in the formation of non-active polymer forms. DSC measurements resulted in $T_{\max }$ values which are the indicators of protein thermostability. Accordingly, the monomeric, active enzyme is less stable than the polymeric, non-active forms. Furthermore, the Cys320 to Ser point mutation significantly destabilized the BrILL2 enzyme. Based on the mutagenesis experiments it was shown that Cys139 is crucial for the enzyme activity. However ITC, CDS and DSC data showed that Cys139 to Ser mutation did not affect $\mathrm{Mn}^{2+}$ ion binding to the enzyme, suggesting that Cys139 is not crucial for metal binding. The theoretical results revealed that Cys139 is a part of the bimetal active site and participates in the coordination of the metal co-factor $\mathrm{Mn}^{2+}$. While the position of manganese ions in the active site of BrILL2 (wild type) remained stable (their average distance is about $4 \AA$ ) during 200 ns of MD simulations, the metal ions in the BrILL2C139S mutant moved away from each other during the simulations, and after $200 \mathrm{~ns}$ they were separated by about $7 \AA$. According to the molecular modelling results, we assume that the preferred substrate IPA-Ala binds into the BrILL2 active site either in the orientation identified as BM1 or BM2. In each of these orientations, there is a water molecule close to the amide bond carbon appropriate to actively participate in the amide bond hydrolysis, i.e. to be activated and to perform the nucleophilic attack to carbonyl carbon. In the BrILL2wt-IPA-Ala_BM1 complex the water molecule could be activated either by the carboxyl group of Glu151 or by the carboxyl group of the substrate itself, while in the BrILL2wtIPA-Ala_BM2 Glu370 might activate the water molecule. In the C139S mutant (neutral Ser), the active site architecture differs from that in the wild type complexes and this is probably the main reason for its inactivity. However, if we assume that Ser at position 139 is deprotonated, the active site architecture is similar to that in the active site, and the reason for its inactivity is not so obvious. The possible explanations for the inactivity of the ${\mathrm{S} 139 \mathrm{~S}^{-}}^{-}$variant are (a) lower binding affinity for the preferred IPA-Ala substrate in comparison to the wild type enzyme and (b) lack of water molecules appropriate for the nucleophilic attack.

\section{Abbreviations}

\begin{tabular}{|c|c|}
\hline CDS & Circular dichroism spectropolarimetry \\
\hline DSC & Differential scanning calorimetry \\
\hline EDTA & Ethylenediaminetetraacetic acid \\
\hline HR-ICP-MS & $\begin{array}{l}\text { High resolution inductively coupled plasma mass } \\
\text { spectrometry }\end{array}$ \\
\hline IAA & Indole-3-acetic acid \\
\hline IAA-Ala & $\begin{array}{l}\text { Conjugate of indole-3-acetic acid (IAA) with amino } \\
\text { acid alanine (Ala) }\end{array}$ \\
\hline IBA & Indole-3-butyric acid \\
\hline IBA-Ala & $\begin{array}{l}\text { Conjugate of indole-3-butyric acid (IBA) with } \\
\text { amino acid alanine (Ala) }\end{array}$ \\
\hline IPA & Indole-3-propionic acid \\
\hline IPA-Ala & $\begin{array}{l}\text { Conjugate of indole-3-propionic acid (IPA) with } \\
\text { amino acid alanine (Ala) }\end{array}$ \\
\hline
\end{tabular}
IPTG
ITC
PMSF
wt
Isopropyl- $\beta$-D-1-thiogalactopyranoside
Isothermal titration calorimetry
Phenylmethylsulfonyl fluoride
Wild type

\section{Acknowledgements}

We kindly thank Dr sc. Marija Matkovic for help with CDS measurements and Niko Bačić for assistance with HR-ICP-MS analysis. We are also grateful to Dr sc. Marija Abramic for critical reading of the manuscript. This work has been supported by the FP7-REGPOT-2012-2013-1 Grant Agreement no. 316289 and by the Alexander van Humboldt Institutional partnership between Ruđer Bošković Institute and the Technische Universität Dresden.

\section{References}

1 N. D. Rawlings, M. Waller, A. J. Barrett and A. Bateman, Nucleic Acids Res., 2014, 42, D503-D509.

2 C. M. Seibert and F. M. Raushel, J. Biochem., 2005, 44, 6383-6391.

3 J. Ludwig-Müller, J. Exp. Bot., 2011, 62, 1757-1773.

4 C. S. Westfall, A. M. Muehler and J. M. Jez, J. Biol. Chem., 2013, 288, 19304-19311.

5 A. Bajguz and A. Piotrowska, Phytochemicals, 2009, 20, 957-969.

6 B. Bartel and G. R. Fink, Science, 1995, 268, 1745-1748.

7 R. T. Davies, D. H. Goetz, J. Lasswell, M. N. Anderson and B. Bartel, Plant Cell, 1999, 11, 365-367.

8 S. LeClere, R. Tellez, R. A. Rampey, P. T. Seiichi, S. P. T. Matsuda and B. Bartel, J. Biol. Chem., 2002, 277, 20446-20452.

9 J. J. Campanella, A. F. Olajide, V. Magnus and J. LudwigMüller, Plant Physiol., 2004, 135, 2230-2240.

10 J. J. Campanella, S. M. Smith, D. Leibu, S. Wexler and J. Ludwig-Müller, J. Plant Growth Regul., 2008, 27, 26-38.

11 B. Savić, S. Tomić, V. Magnus, K. Gruden, K. Barle, R. Grenković, J. Ludwig-Müller and B. Salopek-Sondi, Plant Cell Physiol., 2009, 50, 1587-1599.

12 E. J. Levin, D. A. Kondrashov, G. E. Wesenberg and G. N. Phillips, Structure, 2007, 15, 1040-1052.

13 E. Bitto, C. A. Bingman, L. Bittova, N. L. Houston, R. S. Boston, B. G. Fox and G. N. Phillips Jr., Proteins, 2009, 74, 61-71.

14 I. Shin, K. Han and S. Rhee, J. Mol. Biol, 2014, 426, 3028-3040.

15 G. Bruylants, J. Wouters and C. Michaux, Curr. Med. Chem., 2005, 12, 2011-2020.

16 P. Privalov, Microcalorimetry of Macromolecules: The Physical Basis of Biological Structures, Wiley, 1st edn, 2012.

17 F. Conejero-Lara, J. M. Sanchez-Ruiz, P. L. Mateo, F. J. Burgos, J. Vendrell and F. X. Aviles, Eur. J. Biochem., 1991, 200, 663-670.

18 J. M. Sanchez-Ruiz, j. L. Lopez-Lacomba, P. L. Mateo, M. Vilanova, M. A. Serra and F. X. Aviles, Eur. J. Biochem., 1988, 176, 225-230. 
19 A. V. Hernandez-Moreno, F. Villasenor, E. Medina-Rivero, N. O. Perez, L. F. Flores-Ortiz, G. Saab-Rincon and G. LunaBarcenas, Int. J. Biol. Macromol., 2014, 64, 306-312.

20 A. K. Werner, I. A. Sparkes, T. Romeis and C.-P. Witte, Plant Physiol., 2008, 146, 418-430.

21 B. B. Buchanan and Y. Balmer, Annu. Rev. Plant Biol., 2005, 56, 187-220.

22 C.-Y. Chen, D. Willard and J. Rudolph, J. Biochem., 2009, 48, 1399-1409.

23 D. Hasse, E. Andersson, G. Carlsson, A. Masloboy, M. Hagemann, H. Bauwe and I. Andersson, J. Biol. Chem., 2013, 288, 35333-35345.

24 M. Jarenmark, H. Carlsson and E. Nordlander, C. R. Chimie., 2007, 10, 433-462.

25 Y. Liu, L. Wei, W. Yaozhui, J. Yindi and T. Xiangshi, Metallomics, 2013, 5, 1448-1457.

26 T. H. Evers, M. A. M. Appelhof, E. W. Meijer and M. Merkx, Protein Eng., Des. Sel., 2008, 21, 529-536.

27 M. Rowinska-Zyrek, D. Witkowska, S. Potocki, M. Remellib and H. Kozlowski, New J. Chem., 2013, 37, 58-70.

28 A. Schuller and J. Ludwig-Müller, New Phytol., 2006, 171, 1-13. 29 M. M. Bradford, Anal. Biochem., 1976, 72, 248-254.

30 N. Jajčanin-Jozić, S. Deller, T. Pavkov, P. Macheroux and M. Abramić, Biochimie, 2010, 92, 89-96.

31 D. D. Mruk and C. Y. Cheng, Spermatog., 2011, 1, 121-122.

32 R. Lundblad, Chemical Reagents for Protein Modification, CRC Press, 3rd edn, 2004, pp. 352.

33 Ž. Fiket, V. Roje, N. Mikac and G. Kniewald, Croat. Chem. Acta, 2007, 80, 91-100.

34 T. S. Girish, B. Vivek, M. Colaco, S. Misquith and B. Gopal, Acta Crystallogr., Sect. F: Struct. Biol. Cryst. Commun., 2013, 69, 103-108.
35 D. A. Case, J. T. Berryman, R. M. Betz, D. S. Cerutti, T. E. Cheatham, III, T. A. Darden, R. E. Duke, T. J. Giese, H. Gohlke, A. W. Goetz, N. Homeyer, S. Izadi, P. Janowski, J. Kaus, A. Kovalenko, T. S. Lee, S. LeGrand, P. Li, T. Luchko, R. Luo, B. Madej, K. M. Merz, G. Monard, P. Needham, H. Nguyen, H. T. Nguyen, I. Omelyan, A. Onufriev, D. R. Roe, A. Roitberg, R. Salomon-Ferrer, C. L. Simmerling, W. Smith, J. Swails, R. C. Walker, J. Wang, R. M. Wolf, X. Wu, D. M. York and P. A. Kollman, AMBER, 2015, University of California, San Francisco.

36 Å. A. Skjevik, B. D. Madej, R. C. Walker and K. Teigen, J. Phys. Chem. B, 2012, 116, 11124-11136.

37 C. J. Dickson, B. D. Madej, A. A. Skjevik, R. M. Betz, K. Teigen, I. R. Gould and R. C. Walker, J. Chem. Theory Comput., 2014, 10, 865-879.

38 W. L. Jorgensen, J. Chandrasekhar, J. D. Madura, R. W. Impey and M. L. Klein, J. Chem. Phys., 1983, 79, 926-935.

39 M. R. Lee, Y. Duan and P. A. Kollman, Proteins, 2000, 39, 309-316.

40 D. A. Case, T. A. Darden, T. E. Cheatham, III, C. L. Simmerling, J. Wang, R. E. Duke, R. Luo, R. C. Walker, W. Zhang, K. M. Merz, B. Roberts, S. Hayik, A. Roitberg, G. Seabra, J. Swails, A. W. Götz, I. Kolossváry, K. F. Wong, F. Paesani, J. Vanicek, R. M. Wolf, J. Liu, X. Wu, S. R. Brozell, T. Steinbrecher, H. Gohlke, Q. Cai, X. Ye, J. Wang, M.-J. Hsieh, G. Cui, D. R. Roe, D. H. Mathews, M. G. Seetin, R. Salomon-Ferrer, C. Sagui, V. Babin, T. Luchko, S. Gusarov, A. Kovalenko and P. A. Kollman, AMBER 12, 2012, University of California, San Francisco.

41 D. A. Case, T. E. Cheatham, T. Darden, H. Gohlke, R. Luo, K. M. Merz, A. Onufriev, C. Simmerling, B. Wang and R. J. Woods, J. Comput. Chem., 2005, 26, 1668-1688. 